\title{
Determination of the Attitudes of the Health Staff Working for the Institutions Providing Primary Health Care Towards Ageism $\infty$
}

\author{
Funda TUNCER SSAHIN ${ }^{1}$,Evrim BAYRAKTAR ${ }^{2}$, Zeliha KAYA ERTEN ${ }^{3}$
}

\begin{abstract}
Aim: This descriptive and correlational study was conducted to determine the attitudes of the health care staff who work for the institutions providing primary health care services in Kayseri. Material and Methods: The study was conducted with 259 individuals who agreed to participate in the study. In the quantitative part of the study, a questionnaire form and the Ageism Attitude Scale were used. In the qualitative part of the research, indepth interviews were conducted with eight health care personnel who had the highest and lowest scores on the Ageism Attitude Scale and agreed to interview. Mann-Whitney $U$, Kruskal-Wallis, and chisquare tests were used to analyze the data. The statistical significance level was taken as 0.05 in all tests.

Results: In the study, it was found that while male health care personnel wanted to live with the elderly, female health care personnel did not $(p<0.05)$. In the mean score distribution of the ageism attitude scale, it was determined that physicians and health officers had higher positive discrimination scores towards the elderly. Nurses' and midwives' negative discrimination scores against the elderly were higher than the other groups $(p<0.05)$. As the education level increased, the scores of positive discrimination against the elderly also increased.

Conclusion: In the research, we can say that healthcare personnel discriminates elderly at different points. The important thing is to reveal the prejudices of the health personnel about the elderly and ensure that the health personnel serving the elderly are aware of these prejudices. We think that this research will give health care professionals an insight.
\end{abstract}

Keywords: Ageism, elderly, health care staff

\begin{abstract}
öz
Birinci Basamak Sağlık Hizmeti Veren Kurumlarda Çalışan Sağlık Personelinin Yaşlı Ayrimcılığına Illişkin Tutumlarının Belirlenmesi

Amaç: Bu çalışma Birinci Basamak Sağlık Hizmeti veren kurumlarda görev yapan sağlık personelinin yaşlı ayrımcılığı hakkındaki tutumunu belirlemek amacıyla tanımlayıcı ve ilişki arayıcı tipte yapılmıştır.

Gereç ve Yöntem: Araştırma çalışmaya katılmayı kabul eden 259 kişi ile tamamlanmıştır. Araştırmanın nicel kısmında sağlık çalışanlarııın sosyodemografik ve aile özelliklerini tespit etmeye yönelik anket formu ve Yaşlı Ayrımcılığı Tutum Ölçeği kullanılmıştır. Araştırmada Yaşlı Ayrımcılığı Tutum Ölçeği (YATÖ) puanları en yüksek ve en düşük çıkan ve görüşme yapmayı kabul eden 8 sağlık personeli ile derinlemesine görüşülmüştür. Verilerin analizinde Mann-Whitney $U$, Kruskal-Wallis ve ki-kare testi kullanılmıştır. Tüm testlerde istatistiksel önem düzeyi 0.05 olarak alınmıştır.

Bulgular: Araştırmada erkek sağlık personeli yaşlı ile birlikte yaşamak isterken, kadın sağlık personelinin istemediği bulunmuştur $(p<0.05)$. Yaşlı ayrımcılığı tutum ölçeği ortalama puan dağılımlarında ise doktor ve sağlık memurlarının yaşlıya yönelik olumlu ayrımclık puanlarının daha yüksek olduğu, hemşire ve ebelerin yaşıya yönelik olumsuz ayrımcılık puanlarının diğer gruplara göre yüksek olduğu belirlenmiştir $(p<0.05)$. Eğitim durumu yükseldikçe yaşlıya yapılan olumlu ayrımcılık puanları da artmaktadır.

Sonuç: Araştırmada sağlık personelinin farklı noktalarda yaşlı ayrımcılığı yaptığını söyleyebiliriz. Önemli olan ise sağlık personelinin yaşı konusundaki ön yargılarının ortaya çıkarılması ve yaşlıya hizmet veren sağlık personelinin bu ön yargılarının farkında olarak hizmet vermelerinin sağlanmasıdır. Bu araştırma ile sağlık çalışanlarına bir iç görü kazandıracağını düşünmekteyiz.

Anahtar kelimeler: Sağık personeli, yaşlı, yaşlı ayrımcılığı
\end{abstract}

\footnotetext{
${ }^{1}$ Lecturer, Aksaray University Health Care Services Department, Elderly Care, Aksaray, Turkey, E-posta: fundatuncersahin@gmail.com, Phone :+90382 2882806, ORCID: 0000-0003-0998-3026

2PHD, Erciyes University, Faculty of Health Sciences, Department of Nursing, Kayseri, Turkey, E-posta: evrim_albayrak@hotmail.com, Phone: +90 352 437 9281, ORCID: 0000-0002-2914-197x

${ }^{3}$ PHD, Nuh Naci Yazgan University, Faculty of Health Sciences, Department of Publich Health Nursing, Kayseri, Turkey, E-posta: kayazkaya@gmail.com, Phone: +903523240000-5151, ORCID: 0000-0003-1229-7350

Geliş Tarihi: 27 Mart 2020, Kabul Tarihi: 30 Mart 2021

Atıf/Citation: Tuncer Şahin F, Bayraktar E, Kaya Erten Z. Determination of the Attitudes of The Health Staff Working for the Institutions Providing Primary Healthcare Towards Ageism. Hacettepe Üniversitesi Hemşirelik Fakültesi Dergisi 2021;8(2):167-177. DOI: 10.31125/hunhemsire.971404
} 


\section{INTRODUCTION}

Aging is a process that continues from birth to death, as in every living thing ${ }^{1-3}$. In this process, individuals experience many physiological, sociological, and psychological changes $^{1-6}$. These changes can cause many problems in the lives of the elderly. As in the world, life expectancy in Turkey has also been increasing, and it causes an increase in the elderly population steadily. The elderly population in the world was found as $9.3 \%$ in 2019. In Turkey, the elderly population increased to $9.1 \%$ in 2019. Population projections estimate that the elderly population will continue to grow. According to the population projections, the rate of the elderly population is projected to be $10.2 \%$ in $2023,12.9 \%$ in $2030,16.3 \%$ in $2040,22.6 \%$ in 2060 , and $25.6 \%$ in $2080^{7}$.

According to the statistics, Turkey is among the developing countries where the aging process is fast ${ }^{6-11}$. Aging often means disability or an increase in disability. With the increase in the disability of the elderly, they need others, and they are more dependent on others for daily activities such as dressing, bathing, moving, and eating ${ }^{12}$. With the rapid increase in the elderly population in developed and developing countries, many individual and social problems emerge. These problems can be stated as the lack of adequate access to health care services, failure to cover health expenditures, inability to benefit from social security institutions and financing, reduced income after retirement, and limited employment opportunities for the elderly ${ }^{8}$. In addition, it is expected that the elderly will face some other problems such as a reduction in social support from their families and their immediate environment, adaptation or non-adaptation to the aging process, accommodation, and daily care ${ }^{8,13}$. With the change in the sociocultural structure of societies, the age perceptions of individuals and society are also changing. Along with the changing age perception, elderly neglect and abuse in the society and problems such as ageism can also be seen ${ }^{8}$.

There are many definitions of ageism in literature, and the most common definition is the one by Palmore. According to this definition, ageism is explained as a term expressed through prejudices, attitudes, and behaviors towards older people ${ }^{1-4,6,10,12,14}$. Recent studies show that the elderly are exposed to discrimination in their families and institutions where they receive service ${ }^{8,15}$. The opinion that the elderly are discriminated in all areas of health care is becoming increasingly common ${ }^{3}$. Ageism is important for people living in all areas of society, but it is much more important for health workers. A positive attitude towards the elderly is predicted to improve the quality of life of the elderly 4 . Especially the attitude of the health care providers who work in primary health care institutions and who have oneto-one contact with the elderly is critical. Studies are revealing that health care providers have negative and positive attitudes towards elderly individuals ${ }^{10,11,16-19}$. Nurses' prejudices, values, beliefs, lack of knowledge, and negative attitudes about ageism are stated to reduce not only the quality of the care given to elderly people but also the self-esteem of elderly individuals ${ }^{20,21}$. Studies conducted on this subject are mostly based on quantitative data $2,3,6,8,11,13,20,22,23$. It is crucial to reveal the prejudices of the health care providers about the elderly and ensure that the health care providers serving the elderly are aware of these prejudices.

Aim

This study was conducted in Kayseri province center and in the central districts to determine the attitude of the health care providers working in primary health care institutions towards the elderly.

\section{MATERIAL and METHODS}

\section{Study Design}

This descriptive study was carried out to determine the attitude of the health care staff working in primary health care institutions in the center of Kayseri and the districts towards the elderly.

\section{Study Sample}

The study was conducted at 42 centers, including primary care clinics (PCC) in Melikgazi, Kocasinan, Talas, Hacılar, and Incesu districts and community health centers (CHC) and home care centers in the center of Kayseri between the years 2016-2017.

The research population consists of 342 health care providers. Sample selection was not made, and all of the healthcare providers working at that time and agreeing to participate in the research were included in the study. The sample of the study consisted of 259 people. The participation rate was $75.73 \%$.

Eight healthcare providers who had the highest and lowest scores after the quantitative evaluation and who agreed to in-depth interviews were interviewed for 10-15 minutes. Interviews were recorded on tape.

\section{Data Collection Tools}

\section{Questionnaire Form}

The questionnaire was formed by literature review and included 29 questions which had 23 questions aiming to define the sociodemographic and family characteristics of the healthcare providers and six questions seeking to determine their states about the elderly 1,2,4-6,11,13.

Ageism Attitude Scale (AAS)

"Ageism Attitude Scale" was used to determine the attitudes of the healthcare providers working at the institutions providing primary health care service towards ageism. Vefikuluçay developed the scale in 2008, and a validity and reliability study (Cronbach Alpha Reliability Coefficient 0.80 ) was conducted ${ }^{1}$. The scale includes 23 items and three subtitles: positive discrimination towards the elderly, negative discrimination towards the elderly, and restricting the life of the elder. In the Ageism Attitude Scale, $1^{\text {st }}, 5^{\text {th }}, 12^{\text {th }}, 14^{\text {th }}, 17^{\text {th }}, 19^{\text {th }}, 21^{\text {st }}, 22^{\text {nd }}$, and $23^{\text {rd }}$ questions are for determining restricting the life of the elder, $2^{\text {nd }}, 4^{\text {th }}, 6^{\text {th }}$, $7^{\text {th }}, 8^{\text {th }}, 9^{\text {th }}, 13^{\text {th }}$ and $20^{\text {th }}$ questions are for positive discrimination towards the elderly, and the $3^{\text {rd }}, 10^{\text {th }}, 11^{\text {th }}$, $15^{\text {th }}, 16^{\text {th }}$, and $18^{\text {th }}$ questions are for negative discrimination towards the elderly. The scale is a 5-point Likert scale, and the participants are asked to answer each phrase as "strongly disagree", "disagree," "undecided", "agree" and "strongly agree." When assessing the scale, for the phrases 
including positive discrimination towards the elderly, "strongly agree" is scored as 5, "agree" as 4, "undecided" as 3 , "disagree" as 2, and "strongly disagree" as 1 . For negative expressions for ageism, "strongly agree" is scored as 1 , "agree" as 2, "undecided" as 3, "disagree" as 4, and "strongly disagree" as 5 . The maximum score obtained from the scale is 115 , and the minimum score is $23^{1}$ (the study about validity and reliability is given in the References). In our study, Cronbach Alpha Reliability Coefficient is 0,68.

\section{In-Depth Interview Form}

In the in-depth interview part of the study, a semistructured questionnaire form was used. The questions were formed by consulting two specialist lecturers and by depending on the literature ${ }^{1,2,4,6,16}$. In the interview form used in the interviews with the health care providers, the following topics were identified as themes.

In-depth interview themes

- Opinion on the physical appearance of the elderly

- Opinion on the psychology of the elderly

- Opinion on the participation of senior citizens in working life

- Opinion about the sexual life of the elderly

- Opinion on neglect, abuse, and violence against the elderly

\section{Data Collection}

The researcher collected the quantitative data the same day after the questionnaires were distributed and filled in between May 2016 and April 2017. A team including a moderator and a reporter conducted the in-depth reviews. The voice recording method was used to record the data obtained by the interviews. The same person performed the interviews to get a valid and reliable result.

\section{Data Analysis}

The data obtained from the research were evaluated by using IBM SPSS Statistics 21.0 (Chicago, USA) statistical package. The normality test was applied with the Kolmogorov-Smirnov (K-S) test to determine whether the data showed normal distribution and the data distribution was not normal24. Mann-Whitney $U$ test was used to compare two independent groups, and the Kruskal-Wallis test was used to compare three or more groups. Chi-square test $\left(X^{2}\right)$ was used to compare the categorical variables. For the values below 5, Fisher's Exact Chi-square test was used. The value of $p<0.05$ was accepted as significant.

After the qualitative data were decoded by the researcher, records and the record inventory were examined by three other lecturers to ensure the reliability of the data, and they were compared with the researchers' inventory. The qualitative data were presented in the determined thematic fields afterward the quantitative data.

\section{Ethical Approval}

Necessary permissions were obtained from the institutions where the research would be carried out. Also, after the approvals from the academic board and Erciyes University Ethics Committee (2016/21) received, institutions were applied for permission. The research was started after obtaining the necessary permissions. The health care staff who participated in the study were informed about the research content, and their written and verbal consents were obtained before conducting the questionnaire.

\section{Research participation criteria}

All health care providers working at the primary health care institutions and accepting to participate in the study were included in the study.

\section{Research variables}

Dependent variables consist of the data obtained from the Ageism Attitude Scale.

Independent variables consist of the demographic characteristics of the healthcare providers, such as profession and age.

\section{Limitations}

The limitation of this study is that the research was done in only one city. Therefore, the findings cannot be generalized to all primary health care professionals; generalization can be made only for health care professionals working in institutions where the research was conducted. In addition, the fact that the validity and reliability study of the "Ageism Attitude Scale" used in the study was conducted on university students but not on health care professionals can be seen as a limitation for the research. Although the Cronbach alpha coefficient found in the study is an acceptable value as 0.68 , it is believed that it was resulted as so depending on the sample selection. It is believed that developing and conducting a scale measuring the ageism attitudes of the health care professionals is necessary for the reliability of the findings for the researchers desiring to carry on studies on the issue.

\section{RESULTS}

The average age of the healthcare providers participating in the study is $39.2 .67 .6 \%$ of the participants are female, and $32.4 \%$ are male. $37.5 \%$ of the staff are physicians, $26.3 \%$ are midwives, and $24.7 \%$ are nurses. $46 \%$ of them have a bachelor's degree, and the tenure of $43.6 \%$ is 20 years and above. $87.6 \%$ of the staff are married, $93.8 \%$ have a nuclear family structure, $20.5 \%$ do not have children, and $58.3 \%$ have children. The income of $64.9 \%$ of the health care staff is equal to their expenses (Table 1).

Table 1. Distribution of Demographic Characteristics of Health Care Providers $(n=259)$

\begin{tabular}{|c|c|c|c|c|c|}
\hline $\begin{array}{l}\text { Demographic } \\
\text { Characteristics }\end{array}$ & $\mathrm{n}$ & $\%$ & $\begin{array}{l}\text { Demographic } \\
\text { Characteristics }\end{array}$ & 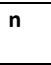 & $\%$ \\
\hline \multicolumn{3}{|l|}{ Age } & \multicolumn{3}{|l|}{ Education } \\
\hline $18-24$ & 18 & 6.9 & PhD & 6 & 2.3 \\
\hline $25-34$ & 47 & 18.1 & MSc & 38 & 14.7 \\
\hline $35-44$ & 117 & 45.5 & Associate & 59 & 22.8 \\
\hline $45-54$ & 71 & 27.4 & Bachelor & 121 & 46.7 \\
\hline $55-64$ & 6 & 2.3 & High School & 35 & 13.5 \\
\hline \multicolumn{3}{|l|}{ Gender } & \multicolumn{3}{|l|}{ Marital Status } \\
\hline Female & 175 & 67.6 & Married & 227 & 87.6 \\
\hline Male & 84 & 32.4 & Single & 30 & 11.6 \\
\hline \multicolumn{3}{|l|}{ Occupation } & \multicolumn{3}{|c|}{ Working Year in the Profession } \\
\hline Physician & 97 & 37.5 & 1-4 years & 23 & 8.9 \\
\hline Midwife & 68 & 26.3 & $5-9$ years & 27 & 10.4 \\
\hline Nurse & 64 & 24.7 & $10-14$ years & 43 & 16.6 \\
\hline Health Officer & 14 & 5.4 & $15-19$ years & 53 & 20.5 \\
\hline Others & 16 & 6.2 & $\begin{array}{l}20 \text { years and } \\
\text { above }\end{array}$ & 113 & 43.6 \\
\hline
\end{tabular}


Table 1. Distribution of Demographic Characteristics of Health Care Providers( $n=259$ ) (continous)

\begin{tabular}{|l|l|l|l|l|l|}
\hline Family Type & $\mathbf{n}$ & $\mathbf{\%}$ & $\begin{array}{l}\text { Number of } \\
\text { Children }\end{array}$ & $\mathbf{n}$ & $\%$ \\
\hline Nuclear & 242 & 93.8 & $1-2$ & 151 & 58.3 \\
\hline Extended & 16 & 6.2 & $3-4$ & 55 & 21.2 \\
\hline \multicolumn{7}{|l|}{} & 168 & 64.9 & & None & 53 & 20.5 \\
\hline Monthly Income & $\begin{array}{l}\text { Income equals } \\
\text { expense }\end{array}$ & 21.2 & & 259 & 100 \\
\hline $\begin{array}{l}\text { Income is more } \\
\text { than the expense }\end{array}$ & 55 & 26 & 13.9 & & \\
\cline { 1 - 3 } $\begin{array}{l}\text { Income is less } \\
\text { than the expense }\end{array}$ & 369 & 100 & & & \\
\cline { 1 - 4 } Total & 259 & & \\
\hline
\end{tabular}

$59.1 \%$ of the healthcare providers reported that they lived with an elderly individual in any period of their lives, and $44.4 \%$ reported that they lived with their grandmothers/grandfathers. $14.7 \%$ of them reported that they lived with their parents after they got married. 39.6\% of the healthcare providers stated that they lived with an elderly individual for $1-4$ years, and $29.9 \%$ lived with an elderly individual for $11-16$ years. $13.6 \%$ of them indicated that their role in elderly care was providing healthcare, the role of $42.9 \%$ was to support the elderly in their daily life skills, and $43.5 \%$ stated that the elderly they live with did not need care (Table 2). $54.4 \%$ of the health care staff included in the study do not want to live with their parents after they get married. $52.5 \%$ of the health care staff who do not want to live with their parents state that they do not want to disarrange; $18.6 \%$ claim that they have conflicts in communication with the elderly; $12.4 \%$ state that the elderly want to live independently, and $11.5 \%$ indicate that their houses are small and they have a busy life. 5.3\% of them do not present a reason of their unwillingness to live with the elderly. $28 \%$ of the healthcare staff who stated they did not want to live with the elderly did not state any reason. $45 \%$ of the healthcare providers want to live with their parents after they start their own family. $32.7 \%$ of the staff want to live with the elderly since they have love and respect. $30.2 \%$ of them accept caring for the elderly as a responsibility. $25.9 \%$ consider the comfort of themselves and the elderly. $11.2 \%$ of them want to improve their family ties, and they see the elderly as guides to themselves. 2 healthcare providers stated that they wanted to live with the elderly, but they did not state any reasons for this.

Table 2. Distribution of Health Care Provider's Living with an Elderly and Their Living Conditions

\begin{tabular}{|l|c|c|}
\hline $\begin{array}{l}\text { The state of living with an elderly in any } \\
\text { period of one's life } \mathbf{n = 2 5 9}\end{array}$ & $\mathbf{n}$ & \% \\
\hline I lived & 154 & 59.1 \\
\hline I did not live & 105 & 40.9 \\
\hline $\begin{array}{l}\text { The elderly who had been lived with so } \\
\text { far } \mathbf{n ( 2 5 9 )}\end{array}$ & \multicolumn{2}{|l|}{} \\
\hline Grandmother-Grandfather & 116 & 44.4 \\
\hline None & 105 & 40.9 \\
\hline Parents after Marriage & 38 & 14.7 \\
\hline
\end{tabular}

Table 2. Distribution of Health Care Provider's Living with an Elderly and Their Living Conditions (continuos)

\begin{tabular}{|c|c|c|}
\hline $\begin{array}{l}\text { Time Spent with the Elderly in the Same } \\
\text { House } n(154)\end{array}$ & n & $\%$ \\
\hline $1-4$ years & 61 & 39.6 \\
\hline $5-10$ years & 47 & 30.5 \\
\hline 11 and above & 46 & 29.9 \\
\hline \multicolumn{3}{|l|}{$\begin{array}{l}\text { Role in the Care of the Elderly } \\
\mathrm{n}(154)\end{array}$} \\
\hline Supporting daily life skills & 67 & 43.5 \\
\hline No care needs & 66 & 42.9 \\
\hline Health care & 21 & 13.6 \\
\hline \multicolumn{3}{|c|}{$\begin{array}{l}\text { The Desire to Live with Parents after Starting Their Own } \\
\text { Family n (259) }\end{array}$} \\
\hline I do not want & 141 & 54.4 \\
\hline I want & 118 & 45.6 \\
\hline \multicolumn{3}{|l|}{ The Reason of the Desire $n(116)$} \\
\hline Love and respect to the elderly & 38 & 32.7 \\
\hline $\begin{array}{l}\text { To consider the care of the elderly as a } \\
\text { responsibility }\end{array}$ & 35 & 30.2 \\
\hline $\begin{array}{l}\text { For the comfort of the elderly and } \\
\text { themselves }\end{array}$ & 30 & 25.9 \\
\hline $\begin{array}{l}\text { To desire to improve family ties and to } \\
\text { see the elderly as guides }\end{array}$ & 13 & 11.2 \\
\hline \multicolumn{3}{|l|}{ The Reason of Unwillingness $n$ (113) } \\
\hline I don't want to disarrange my life & 59 & 52.2 \\
\hline Conflicts in communication & 21 & 18.6 \\
\hline $\begin{array}{l}\text { The elderly want to maintain their } \\
\text { independence }\end{array}$ & 14 & 12.4 \\
\hline Small houses and busy life conditions & 13 & 11.5 \\
\hline No reason & 6 & 5.3 \\
\hline
\end{tabular}

In Table 3, sociodemographic characteristics of the healthcare staff and their state of willingness to live with the elderly were compared. When gender and willingness for living with the elderly were compared, it was found that male staff reported their willingness for living with the elderly more than the female ones $(p<0.05)$. A statistically significant difference was found between the occupation groups and the willingness to live with the elderly. Physicians and health officers are more willing to live with the elderly when compared to midwives and nurses $(p<0.05)$. The state of living in an extended family in childhood and willingness to live with the elderly were examined. $52.0 \%$ of the healthcare providers who had lived in an extended family were willing to live with an elderly, and $60.3 \%$ of the healthcare providers who had not lived in an extended family stated that they did not want to live with the elderly $(p<0.05)$. 
Table 3. The Desire to Live with the Elderly according to the Demographic Data of the Health Care Providers

Descriptive Characteristics The Desire to Live with the Elderly

\begin{tabular}{|c|c|c|c|c|}
\hline & \\
\hline & I want & $\%$ & I don't want & $\%$ \\
\hline \multicolumn{5}{|l|}{ Gender } \\
\hline Female & 62 & 35.4 & 113 & 64.6 \\
\hline Male & 56 & 66.7 & 28 & 33.3 \\
\hline Total & 118 & 45.6 & 141 & 54.4 \\
\hline Test statistics $\left(\mathrm{X}^{2}\right)$ & \multicolumn{4}{|c|}{$22.330^{a}$} \\
\hline$p$ & \multicolumn{4}{|c|}{0.000} \\
\hline \multicolumn{5}{|l|}{ Marital Status } \\
\hline Married & 106 & 46.7 & 121 & 53.3 \\
\hline Single & 12 & 37.5 & 20 & 62.5 \\
\hline Total & 118 & 45.6 & 141 & 54.4 \\
\hline Test statistics $\left(\mathrm{X}^{2}\right)$ & \multicolumn{4}{|c|}{$0.956^{a}$} \\
\hline$p$ & \multicolumn{4}{|l|}{0.580} \\
\hline \multicolumn{5}{|l|}{ Occupation } \\
\hline Physician & 53 & 54.6 & 44 & 45.4 \\
\hline Nurse & 22 & 34.4 & 42 & 65.6 \\
\hline Health officer & 9 & 64.3 & 5 & 35.7 \\
\hline Midwife & 23 & 33.8 & 45 & 66.2 \\
\hline Others & 11 & 68.8 & 5 & 31.3 \\
\hline Total & 118 & 45.6 & 141 & 54.4 \\
\hline Test statistics $\left(\mathrm{X}^{2}\right)$ & \multicolumn{4}{|c|}{$15.676^{\mathrm{a}}$} \\
\hline$p$ & \multicolumn{4}{|l|}{0.003} \\
\hline \multicolumn{5}{|l|}{ Education } \\
\hline $\mathrm{PhD}$ & 2 & 33.3 & 4 & 66.7 \\
\hline MSc & 23 & 60.5 & 15 & 39.5 \\
\hline Bachelor & 58 & 47.9 & 63 & 52.1 \\
\hline Associate & 19 & 32.2 & 40 & 67.7 \\
\hline High school & 16 & 45.7 & 19 & 54.3 \\
\hline Total & 118 & 45.6 & 141 & 54.4 \\
\hline Test statistics $\left(\mathrm{X}^{2}\right)$ & \multicolumn{4}{|c|}{$8.316^{\mathrm{a}}$} \\
\hline $\mathrm{p}$ & \multicolumn{4}{|l|}{0.081} \\
\hline \multicolumn{5}{|c|}{ Working year in the profession } \\
\hline $1-4$ years & 9 & 39.1 & 14 & 60.9 \\
\hline $5-9$ years & 12 & 44.4 & 15 & 56.6 \\
\hline $10-14$ years & 17 & 39.5 & 26 & 60.5 \\
\hline $15-19$ years & 25 & 47.2 & 28 & 52.8 \\
\hline 20 years and above & 55 & 48.7 & 58 & 51.3 \\
\hline Total & 118 & 45.6 & 141 & 54.4 \\
\hline Test Statistics $\left(\mathrm{X}^{2}\right)$ & \multicolumn{4}{|l|}{$1.523^{\mathrm{a}}$} \\
\hline $\mathrm{p}$ & \multicolumn{4}{|l|}{0.823} \\
\hline \multicolumn{5}{|l|}{ Monthly Income } \\
\hline $\begin{array}{l}\text { Income is less than the } \\
\text { expense }\end{array}$ & 16 & 44.4 & 20 & 55.6 \\
\hline Income equals expense & 70 & 41.7 & 98 & 58.3 \\
\hline $\begin{array}{l}\text { Income is more than the } \\
\text { expense }\end{array}$ & 118 & 45.6 & 141 & 54.4 \\
\hline Total & 118 & 45.6 & 141 & 54.4 \\
\hline Test Statistics $\left(\mathrm{X}^{2}\right)$ & \multicolumn{4}{|c|}{$4.577^{\mathrm{a}}$} \\
\hline $\mathrm{p}$ & \multicolumn{4}{|c|}{0.101} \\
\hline Extended family life during & childhoo & & & \\
\hline Yes & 64 & 52.0 & 59 & 48.0 \\
\hline No & 54 & 39.7 & 82 & 60.3 \\
\hline Test statistics $\left(\mathrm{X}^{2}\right)$ & $3.957^{\mathrm{a}}$ & & & \\
\hline$p$ & 0.047 & & & \\
\hline
\end{tabular}

In Table 4, the demographic data of the healthcare providers were compared with the total score and subscore averages of the ageism attitude scale. When the difference between females and males was examined, no difference was found between the total average score and the average score of restricting the life of the elder. The averages of the positive and negative discrimination towards the elderly were found statistically different. While the male health care providers' score average of the positive discrimination towards the elderly was higher, the female health care providers' score average of the negative discrimination towards the elderly was higher $(p<0.05)$. When the distributions of the average scores of the ageism attitude scale were examined in terms of age groups, the difference between the distributions of positive and negative discrimination average scores was found statistically significant $(p<0.05)$. The difference arises from the health care providers between the ages $18-28$ and $55-64$. While the positive discrimination average score of the health care providers between the ages of 55-64 is higher, the negative discrimination average score of the health care providers between the ages of 18-24 is higher. The willingness to live with the elderly after starting a family was compared with the average scores of the ageism attitude scale. It was found that the positive discrimination average scores of the health care providers who wanted to live with the elderly were higher $(p<0.05)$. In addition to these findings, a participant stated in our qualitative data that "Old age could be nice, we can think of it as maturity, but until when? Until one cannot stand on his/her own! I think, after that, it is a misery for the elderly and a burden for the person taking care of him/her..." (K.Ç., 50, female, nurse). 
Table 4. The Distribution of the AAS Average Scores according to the Demographic Data of the Health Care Providers

\begin{tabular}{|c|c|c|c|c|c|c|}
\hline \multicolumn{7}{|c|}{ The Score Averages of Ageism Attitude Scale } \\
\hline & \multirow[t]{2}{*}{$\mathrm{n}$} & \multirow[t]{2}{*}{$\%$} & \multirow{2}{*}{$\begin{array}{l}\text { Total Score } \\
\text { Median (25-75)\% }\end{array}$} & \multirow{2}{*}{$\begin{array}{l}\text { Restricting the life of } \\
\text { the Elder } \\
\text { Median (25-75)\% } \\
\end{array}$} & \multirow{2}{*}{$\begin{array}{l}\text { Positive Discrimination } \\
\text { Towards the Elderly }\end{array}$} & \multirow{2}{*}{$\begin{array}{l}\text { Negative } \\
\text { Discrimination } \\
\text { Towards the Elderly } \\
\text { Median (25-75)\% } \\
\end{array}$} \\
\hline & & & & & & \\
\hline \multicolumn{7}{|l|}{ Gender } \\
\hline Female & 175 & 67.6 & $65.72 \%(62-71)$ & $19.26 \%(17-21)$ & $29.33 \%(27-33)$ & $17.12 \%(15-19)$ \\
\hline Male & 84 & 32.4 & $66.10 \%(63-70)$ & $18.64 \%(17-21)$ & $31.66 \%(30-34)$ & $15.79 \%(14-18)$ \\
\hline \multicolumn{3}{|c|}{ Test Statistics } & -0.43 & -1.26 & -3.86 & -3.25 \\
\hline \multicolumn{3}{|c|}{$\mathbf{p}$} & 0.662 & 0.205 & 0.000 & 0.001 \\
\hline \multicolumn{7}{|l|}{ Age } \\
\hline $18-24$ & 18 & 6.9 & $70.00 \%(65.75-75.25)$ & $19.55 \%(17-22.25)$ & $31.11 \%(30-32)$ & $19.33 \%(18.50-21.50)$ \\
\hline $25-34$ & 47 & 18.1 & $65.42 \%(61-71)$ & $19.65 \%(17-22)$ & $28.00 \%(26-31)$ & $17.68 \%(15-21)$ \\
\hline $35-44$ & 117 & 45.5 & $65.27 \%(62-70)$ & $18.82 \%(17-21)$ & $30.10 \%(27-34)$ & $16.35 \%(14-18)$ \\
\hline $45-54$ & 71 & 27.4 & $65.64 \%(64-69)$ & $18.83 \%(17-21)$ & $30.95 \%(29-34)$ & $15.85 \%(14-18)$ \\
\hline $55-64$ & 6 & 2.3 & $70.16 \%(66.25-74)$ & $20.33 \%(18.50-22.25)$ & $32.16 \%(30.50-33.50)$ & $17.66 \%(14-20.25)$ \\
\hline \multicolumn{3}{|c|}{ Test Statistics } & 11.20 & 4.98 & 13.71 & 21.45 \\
\hline \multicolumn{3}{|c|}{$\mathbf{p}$} & 0.024 & 0.289 & 0.008 & 0.000 \\
\hline \multicolumn{7}{|c|}{ The state of willingness for living with the elderly after starting their own family } \\
\hline I want & 118 & 45.6 & $66.17 \%(63-71)$ & $18.75 \%(17-21)$ & $31.07 \%(29-35)$ & $16.34 \%(14-19)$ \\
\hline $\begin{array}{l}\text { I do not } \\
\text { want }\end{array}$ & 141 & 54.4 & $65.56 \%(61-70)$ & $19.31 \%(17-21.50)$ & $29.26 \%(27-33)$ & $16.98 \%(15-19)$ \\
\hline \multicolumn{3}{|c|}{ Test Statistics } & -1.178 & -1.475 & -3.35 & -1.52 \\
\hline \multicolumn{3}{|l|}{$p$} & 0.239 & 0.140 & 0.001 & 0.127 \\
\hline
\end{tabular}

In Table 5, when the occupational groups and the score averages of the ageism attitude scale were examined, it was determined that the physicians' and health officers' positive discrimination attitude average scores were higher than nurses' and midwives' $(p<0.05)$. The question that "What do you think about the 60 years old and above individuals' participation in production and work life?" was asked, and a female physician stated her positive opinions on that "... if they are strong enough, of course, they should participate. As long as their health is convenient, they can. Many people can participate. They can share their knowledge. They cannot participate in the active works requiring physical strength, but they can participate in different works. Even they can advise at homes; sharing experience can be sufficient..." (E.A., 47, female, physician). On the other hand, a nurse participant answered the same question by stating her negative thoughts about old age and the elderly by saying that "... I think they cannot participate in the production. I don't think they can, but I wish they could do. Then they feel more peaceful and happier. They feel that they serve a purpose. For example, I wish they had hobbies such as making flowers or beading as a part of community health. I think it will be very good for them to be interested in something even if they cannot do properly..." (K.Ç., 50, female, nurse). According to the comparison of the education levels and ageism attitude scale, it was found that high school graduates' negative discrimination score averages were high, and the positive discrimination score averages of those having MSc and PhD degrees were higher $(p<0.05)$. As the education level gets lower, the negative ageism score increases. When the working year in the profession and ageism attitude scale were compared, it was found that the negative discrimination score of the health care staff who had been working for 1-5 years was higher $(p<0.05)$. As the working year in the profession increases, the negative ageism score decreases. 
Table 5. The Distribution of the Average Scores of AAS in terms of the Demographic Data of the Health Care Providers

\begin{tabular}{|c|c|c|c|c|c|}
\hline & & \multicolumn{4}{|c|}{ The Score Averages of Ageism Attitude Scale } \\
\hline & \multirow[t]{2}{*}{$\mathrm{n}-\%$} & Total Score & $\begin{array}{l}\text { Restricting the life of } \\
\text { the Elder }\end{array}$ & $\begin{array}{l}\text { Positive Discrimination } \\
\text { Towards the Elderly }\end{array}$ & $\begin{array}{l}\text { Negative Discrimination } \\
\text { Towards the Elderly }\end{array}$ \\
\hline & & Median (25-75)\% & Median (25-75)\% & Median (25-75)\% & Median (25-75)\% \\
\hline \multicolumn{6}{|l|}{ Occupation } \\
\hline Physician & $97-37.5$ & $65.83 \%(62-70)$ & $18.68 \%(16.50-21)$ & $31.41 \%(29-34)$ & $15.74 \%(14-18)$ \\
\hline Nurse & $64-24.7$ & $66.40 \%(63.25-71)$ & $20.07 \%(18-22)$ & $28.79 \%(26-32)$ & $17.53 \%(15-19.75)$ \\
\hline Health Officer & $14-5.4$ & $67.64 \%(62.75-71.50)$ & $19.42 \%(18-22.25)$ & $31.00 \%(27.25-34.50)$ & $17.21 \%(14.75-20.25)$ \\
\hline Midwife & $68-26.3$ & $64.36 \%(59-70)$ & $18.50 \%(16-20)$ & $29.02 \%(27-32)$ & $16.83 \%(15-19)$ \\
\hline Others & $16-1.7$ & $68.37 \%(64.25-74.50)$ & $19.37 \%(18-20.75)$ & $30.93 \%(30-30.75)$ & $18.06 \%(13.75-21.75)$ \\
\hline \multicolumn{2}{|l|}{ Test Statistics } & 5.560 & 8.890 & 19.067 & 13.507 \\
\hline $\mathbf{p}$ & & 0.235 & 0.064 & 0.001 & 0.009 \\
\hline \multicolumn{6}{|l|}{ Education } \\
\hline $\mathrm{PhD}$ & $6-2.3$ & $64.50 \%(62.25-66.25)$ & $16.66 \%(15.25-18.25)$ & $32.83 \%(30.50-34.75)$ & $15 \%(14.50-16)$ \\
\hline MSc & $38-14.7$ & $65.13 \%(61.75-70)$ & $18.71 \%(16-21)$ & $31.05 \%(27-35)$ & $15.36 \%(14-18)$ \\
\hline Bachelor & $59-22.8$ & $65.61 \%(62-71)$ & $19.12 \%(17-21)$ & $30.03 \%(28-33.50)$ & $16.45 \%(14.50-18.50)$ \\
\hline Associate & $121-46.7$ & $65.52 \%(60-69)$ & $18.64 \%(17-20)$ & $28.83 \%(26-32)$ & $17.05 \%(15-19)$ \\
\hline High school & $35-13.5$ & $69.88 \%(65-75)$ & $20.34 \%(18-23)$ & $30.88 \%(30-32)$ & $18.65 \%(15-21)$ \\
\hline \multicolumn{2}{|l|}{ Test Statistics } & 14.69 & 9.90 & 9.99 & 18.95 \\
\hline p & & 0.005 & 0.042 & 0.041 & 0.001 \\
\hline \multicolumn{6}{|c|}{ Working year in the profession } \\
\hline $1-4$ years & $9-39.1$ & $67.39 \%(66-74)$ & $19.82 \%(17-22)$ & $29.04 \%(28-32)$ & $18.52 \%(17-21)$ \\
\hline $5-9$ years & $12-44.4$ & $67.25 \%(62-70)$ & $19.44 \%(17-21)$ & $29.77 \%(27-32)$ & $18.03 \%(16-20)$ \\
\hline $10-14$ years & $17-39.5$ & $65.79 \%(61-71)$ & $18.93 \%(17-21)$ & $29.83 \%(26-34)$ & $17.02 \%(15-19)$ \\
\hline $15-19$ years & $25-47.2$ & $65.05 \%(61.50-70.50)$ & $18.75 \%(17-20.50)$ & $30.41 \%(28-33)$ & $15.88 \%(14-18)$ \\
\hline 20 years and above & $55-48.7$ & $65.58 \%(63-69.50)$ & $19.00 \%(17-21)$ & $30.31 \%(28-33.50)$ & $16.25 \%(14-18)$ \\
\hline \multicolumn{2}{|l|}{ Test Statistics } & 7.292 & 3.09 & 2.702 & 17.79 \\
\hline \multicolumn{2}{|l|}{$\mathbf{p}$} & 0.121 & 0.543 & 0.609 & 0.001 \\
\hline
\end{tabular}

The participants were asked about their thoughts on old age. $66 \%$ of them stated their thoughts as compassion. $17.3 \%$ defined old age as a disease, $9.6 \%$ as a dependency, $2.8 \%$ as weakness, and $1.9 \%$ as wisdom. In addition to these findings, E.A. (47, female, physician) stated for our qualitative data that "...people are in the mood of old age after a certain age. They are in the mood that they have some problems due to their age. Generally, they are heading for a fall. I think that if people are healthy, they should be as old as they feel psychologically. Being away from their children, being dependent, and having some chronic diseases can affect people psychologically. I think people are not at the physical age, but they are as old as they feel if they are healthy..."

R.H (43, female, lab technician) statement: "I think young individuals do not understand old individuals entirely. Ummm... the reason for this is those young individuals do not want to engage in old individuals. They don't want to engage in dialogue. Now technology has improved, there are cell phones, that is, they prefer to engage in their social life rather than in the elderly. The elderly expect attention and love from the young. They want the others to be interested and chat with them. Ummm... They want warm communication, but they do not have that."
The statement of Ö.G. (43, female, midwife), on how she sees the psychology of the elderly: "The elderly think that they are neglected by their children, daughters-in-law, and grandchildren as I have observed the patients who come here. They have a longing for the past. In the past, they were all together. Now they think they are alone. They want to live together, so I don't think they are in a good mood. Their expectations from the young are too much. They expect from their children, from other people; they always expect things from others. They make themselves unhappy since they have too many expectations."

The statement of M.A. (39, male, health officer) on what he thinks about the psychological health state of the elderly: "Even if they have raised strong individuals, the elderly are not benefited much psychologically after a certain age. I see they isolate themselves, and I think this affects them psychologically very much. I think society pushes them, pushes them to loneliness. This is so in our society. I don't know if this is so in other societies, I haven't searched about it. However, as we see, the elderly are more active in other societies. They are more active than the ones we see in our environment. They are more social. I feel that the elderly in our society isolate themselves, and also we push them to retire into their shells."

The statement of G.B. (42, female, midwife) about the old age and the participation of the elderly in working life: "I 
think they should be in working life to benefit from their wide experiences, but perhaps there can be works they cannot put up with. In this case, they can take passive roles. These roles may be in the management, or their experiences can be benefitted. There are many professors above the ages 65 and 70 in our country or the world. How can we isolate people who have devoted themselves to society? They have made a great effort. How can we isolate people at that age? We have cardiac surgeons above 70 years old. Can we isolate these people by saying that they are old?"

\section{DISCUSSION}

Most of the health care providers included in the research are females (Table 1). Generally, women provide care for the elderly in the world and our country. With the involvement of women in working life, it is thought that the load of elderly care on women, who are exposed to every type of gender apartheid, especially in our country, has increased. It is thought that this burden results in the situation that the women participating in the working life do not want to take the responsibility of the elderly individuals'care at home ${ }^{25,26}$.

In Turkish society, it is important to respect the elderly, listen to their advice, and look after them ${ }^{1,27}$. The rate of the health care providers stating that they wanted to live with their parents was $45.6 \%$, and $32.7 \%$ of them indicated that they felt love and respect for the elderly, $30.3 \%$ stated that looking after the elderly was a responsibility, and $11.2 \%$ stated that they wanted to improve their family ties (Table 2). They said that elderly individuals were good guides, and it was better to live together to comfort the elderly and themselves. The number of people who want to live with the elderly decreases due to the changing social structure, rural-urban migration, nuclear family's becoming widespread, small houses, and people's desire to spend more time with their nuclear family 4,5,28. When the reasons for the unwillingness to live with the elderly (parents) were examined, the participants mentioned the conflicts in communication, small houses, and busy life conditions. Female health care providers stated the willingness to live with the elderly less than the male ones $(p<0.05)$ (Table 3$)$. In the literature, some studies reveal that there is no difference in ageism in terms of gender ${ }^{1,13,29-31}$, but others reveal that there is a difference ${ }^{4,20,25,32}$. In this study, negative ageism scores of females were found higher when compared to males $(p<0.05)$ (Tablo 3$)$. This result may be because women have many responsibilities both at work and at home. In Turkey, care of the elderly is usually the responsibility of women according to gender roles. The women providing care expect support from others, and they also expect the elderly to take their responsibilities. When these expectations fail to be satisfied, they may not want to provide care.

When the state of willingness to live with the elderly was examined in terms of occupational groups, most physicians, health officers, emergency medical technicians, and lab technicians were willing to live with the elderly. However, most nurses and midwives did not want to live with an elderly individual $(p<0.05)$ (Table 3$)$. In the comparison of the occupational groups with the score averages they obtained from the scale, the difference was statistically significant $(p<0.05)$ (Table 3$)$. The positive discrimination score averages of the physicians and health officers were found higher than the other occupational groups. The negative discrimination score averages of the nurses and midwives were found higher than the other occupational groups. The majority of the physicians and all health officers included in the study were males, and the whole nurses and midwives were females. This conforms to the other data obtained from the research. According to the study conducted by Ögender et al., physicians take a positive attitude towards the elderly ${ }^{33-35}$. This result is similar to our findings.

"How their appearance should be? They should take good care of themselves. They should be dressed as they are happy. Of course, some need to use canes. Umm.. in our society, there is so much vitamin D deficiency and osteolysis, so their body can be bent. I don't know if I would express this physical appearance as the appearance. That is .. umm.. I think.. years ago...as we have learned that people at the age of 40, our parents.. they do not wear red clothes, colorful clothes. They were in the mood of being elderly. However, as I said, I am about 50, and I wear red clothes, pink ones and also purple ones.. that is I prefer the colors that I like." (E.A., 47, female, physician).

"I don't think they will be productive after that age. However, as I said, it isn't right for them to take a back seat. They should produce what they can produce, do what they can do. Nobody will find it odd, ummm... nobody will look down on what they do. Ummm... it is important to do what they can. Ummm... neither we nor the society expects great productivity from them. They should do what they can, and they shouldn't take the back seat." (Ö.G., 43, female, midwife).

"I don't think they can participate in the production. I don't think they can do; I wish they could. Then they would feel more peaceful, happier, and useful. Not the production, but, for example, I wish they had some hobbies such as making artificial flowers or beading, by being a part of society health. I think, even if they cannot do properly, it will be good to try to do something for them." (K.Ç., 50, female, nurse). In addition to the quantitative data, it can be stated that the data obtained from the interviews with the health care providers support the quantitative data when they are evaluated in terms of occupational groups. When the ages of the health care providers were compared with the ageism attitude score averages, it was found that there was a significant difference between the score averages of the participants in the 18-24 age group and the ones in the 5564 age group (Table 4$)(p<0.05)$. Adıbelli et al. found that the participants above 25 had more positive discrimination towards the elderly ${ }^{17}$. Soyuer et al. determined that as the students studying in health care progressed in their education, their attitude towards the elderly became more positive with the effect of the courses they took ${ }^{11}$. In another study, it was found that the young were in a more positive attitude towards the elderly in the later periods of their lives ${ }^{36}$. It was determined that individuals between the 
ages of 25-54 had more negative attitudes towards the elderly. It can be stated that rural-urban migration and nuclear family structure have become more common with the changing social structure. People want to be interested in their own family and do not want to live with the elderly ${ }^{37}$. It was determined that the health care providers between the ages 55-64 had a more positive attitude towards the elderly. In the literature, there are some similar studies ${ }^{4,11}$. World Health Organization (WHO) defines old age as the age of 65 and above. It can be considered that the health care providers between the ages 55-64 had a higher score average since they had more working time in the profession and their ages were close to the age that WHO stated.

However, when the educational status of the health care providers was compared to the ageism attitude score averages, it was found that the average score of the ones who were more highly trained got lower (Table 5) $(p<0.05)$. Yılmaz et al. examined the attitudes of young adults towards ageism in their study. They found that high school and bachelor degree graduates had more positive discrimination towards the elderly when compared to the primary school and secondary school graduates ${ }^{3}$. Külahçı evaluated the ageism in the freshmen and senior nursing students, and he determined that senior students had a more positive attitude than the freshmen. The result was that as the educational status increased, ageism decreased ${ }^{38}$. Ünalan et al. found that university graduates had more negative attitudes when compared with the elementary and high school graduates ${ }^{5}$. When the working year and ageism attitude scale scores were compared, it was seen that the health care providers who worked between 1-5 years revealed more ageism according to the negative discrimination score averages $(p<0.05)$. As the working years in the profession increases, discrimination against the elderly decreases. In the study conducted by Ünalan et al., it was determined that as the working year increases, ageism became more positive ${ }^{5}$. This result is similar to our findings.

While $52.0 \%$ of the health care providers who had lived in an extended family in childhood period were willing to live with the elderly, $60.3 \%$ of the participants who had not lived in an extended family during childhood period stated that they did not want to live with the elderly (Table 3 ). In the study conducted by Ünalan et al., it was detected that individuals living in an extended family spend more time with the elderly, and they have positive thoughts about the elderly ${ }^{5}$. Living in an extended family and having been accustomed to this situation can comfort individuals about the willingness to live with an elderly ${ }^{39,40}$. However, people who have grown up in a nuclear family may not want to give up their lifestyles (having their own bedroom and having only their own rules). This case can explain why health care providers growing up in a nuclear family do not want to live with the elderly.

In the research, while some health care providers take old age and getting old as compassion and wisdom, others express their opinions about old age as a disease, dependency, and weakness. In the studies conducted by Külahçı and Adıbelli et al., it is stated that nursing students express their thoughts on the old age as "dependency on someone else, hopelessness, loneliness and poverty" 9,38 . Özdemir and Bilgili state that students report that old age is associated with the concepts of disease, compassion, and weakness ${ }^{4}$. In the related studies, it can be stated that old age is usually associated with negative situations. It can be thought that there are physical, social, and psychological losses with old age, and these might cause negative thoughts. Positive thoughts of the health care providers included in the study are more than negative thoughts.

\section{CONCLUSIONS}

Depending on the data obtained from this research and the statements of the health care providers, it is determined that the participants' thoughts that there is ageism in the society on different points. In addition, it can be stated that health care providers have positive and negative thoughts about old age. It can be thought that especially female health care providers should be trained on ageism and old age so that their risk of discrimination decreases. During the training on ageism, it is thought that the health care providers who work with the elderly will increase their knowledge about old age characteristics, and this knowledge will help health care providers to expand their awareness for the elderly and to be more patient and calmer towards them.

Ethics Committee Approval: Approval was obtained from the Ethics Committee of Erciyes University (2016/21).

Conflict of Interest: Not reported.

Funding: None.

Exhibitor Consent: Informed consent was obtained from health care professionals.

Author contributions:

Study design: FTS, EB, ZKE

Data collection: FTS, EB, ZKE

Data analysis: FTS, EB, ZKE

Drafting manuscript: FTS, EB, ZKE

Acknowledgement: We would like to thank all health care professionals who participated in the study and Bilge Firdevs Gökduman for her supports in the English translation and editing of the manuscript.

Etik Kurul Onayı: Erciyes Üniversitesi Bilimsel Araştırmalar Etik Kurul'undan alınmıştır (2016/21).

Çıkar Çatışması: Bildirilmemiştir.

Finansal Destek: Yoktur.

Katılımcı Onamı: Sağlık personelinden bilgilendirilmiş onam alınmıştır.

Yazar katkıları:

Çalışma dizaynı: FTŞ, EB, ZKE

Veri toplama: FTŞ, EB, ZKE

Veri analizi: FTŞ, EB, ZKE

Makale yazımı: FTŞ, EB, ZKE

Teşekkür: Çalışmaya katılan tüm sağılı personeline teşekkür ederiz. Araştırmaya çeviri ve düzeltme için destek veren Bilge Firdevs GÖKDUMAN'a teşekkür ederiz. 


\section{REFERENCES}

1. Vefikuluçay Yılmaz D, Terzioğlu F. Development and psychometrıc evaluation of ageism attitude scale among the university students. Turkish Journal of Geriatrics. 2011;14(3):259-68.

2. Koç A, Yıldırım R, Gürcü M, Uluçay DV. An evaluation of the behaviours of the college students towards ageism. Ann Eurasian Med. 2013;1(3):49-55.

3. Yılmaz $M$, Altıok $M$, Polat $B$, Darıcı $M$, Sungur MA. Genç erişkinlerin yaşlı ayrımcılığına ilişkin tutumları. Turkish J Geriatr. 2012;15(4):416-23.

4. Özdemir Ö, Bilgili N. Sağlık hizmetlerinde yaşlı ayrımcılığı. Gülhane Med J. 2014;56:128-31.

5. Ünalan D, Soyuer F, Elmalı F. Geriatri merkez çalışanlarının tutumunun değerlendirilmes. Kafkas Med Sci J. 2012;2(3):115-20.

6. Schniter E, Shields TW. Ageism, honesty and trust. J Behav Experimantal Econ. 2014;51:19-29.

7. Demographic change of the elderly population [Internet]. 2020 [Cited 18 Nov 2020]. Available from: https://www.ailevecalisma.gov.tr/media/45354/ age-population-demographic-change-2020.pdf

8. Yılmaz E, Özkan S. Hemşirelik öğrencilerinin yaşlı ayrımcılığına ilişkin tutumları. Maltepe Univ Nurs Sci Art J. 2010;3(2):35-52.

9. Adıbelli D, Türkoğlu N, Kılıç D. Öğrenci hemşirelerin yaşlılığa ilişkin görüşleri ve yaşlılara karşı tutumları. Dokuz Eylul University Faculty of Nursing Electronic Journal [Internet]. 2013 [Cited 3 Jan 2018]. Available from:

https://dergipark.org.tr/tr/pub/deuhfed/issue/4681 $5 / 587074$

10. Güven ŞD, Muz GU, Efe Ertürk N. Üniversite öğrencilerini yaşlı ayrımcılığına ilişkin tutumları ve bu tutumların bazı değişkenlerle ilişkisi. Anadolu Nurs Heal Sci J. 2012;15:99-105.

11. Soyuer F, Ünalan D, Güleser N, Elmalı F. Sağlık meslek yüksek okulu öğrencilerinin yaşlı ayrımcılığına ilişkin tutumları ve bu tutumların bazı demografik değişkenlerle ilişkisi. Mersin University Health Science Journal. 2010;3(2):20-5.

12. Palmore, E. Ageism: Negative and positive. (2nd ed.). New York: Springer Publishing Co; 1999.

13. Akdemir N, Çınar F, Görgülü Ü. Yaşlılığın algılanması ve yaşlı ayrımcılığı. Turkish J Geriatr. 2007;10 (4):21522.

14. Treharne G. Attitudes towards the care of elderly people: are they getting better? J Adv Nurs. 1990;15(7):777-81.

15. Altay $B$, Aydın T. Hemşirelik öğrencilerinin yaşl ayrımcılığına yönelik tutumlarının değerlendirilmesi. Education and Research in Nursing Journal [Internet]. 2015 [Cited 3 Jan 2018]. Available from: http://www.kuhead.org/jvi.aspx?pdir=kuhead\&plng =tur\&un=KUHEAD-79664\&look4=

16. Lee $M$, Reuben DB Ferrell BA. Multidimensional attitudes of medical residents and geriatrics fellows toward older people. West J Emerg Med. 2005;53:489-94.

17. Hughes NJ, Soiza RL, Chua M, Hoyle GE, MacDonald $A$, et al. Medical student attitudes toward older people and willingness to consider a career in geriatric medicine. J Am Geriatr Soc. 2007;56(2):3348.

18. Tel H, Yıldırım M. Yaşlılara verilen hizmeti etkileyen bir faktör: Sağlık çalışanlarının yaşlılara yönelik tutumları. In: 6th National Geriatrics Conference. 2007.

19. Tezcan S, Seçkiner P. Türkiye'de demografik değişim; yaşlılık perspektifi. In: Elderly Health: Problems and Solutions [Internet]. 2012 [Cited 3 Jan 2018]. Available from: http://halksagligiokulu.org/anasayfa/components/c om_booklibrary/ebooks/yaslısaglgiyeni16.7.2012.pd $f$

20. Dinçer $Y$, Usta $E$, Bulduk $S$. Üniversite öğrencileri gözüyle yaşlılık nasıl algılanıyor? Elderly Problems Research Journal [Internet]. 2016 [Cited 3 Jan 2018]. Available from: https://dergipark.org.tr/tr/pub/yasad/issue/23911/ 254823

21. Boz H, Gökçe N, Özüstün Kıral A, Mutlu E, Selvi N, Ünlü $D$, et al. Sağlık bilimleri fakültesi ve iktisadi ve idari bilimler fakültesi öğrencilerinin yaşlı ayrımcılığına ilişkin tutumları. Sağlık Akad Kastamonu [Internet]. 2017 [Cited 3 Jan 2018]. Available from: http://dergipark.gov.tr/doi/10.25279/sak.303050

22. Yılmaz D, Terzioğlu F. Development and psychometric evaluation of ageism attitude scale among the university students. Turkish J Geriatr. 2011;14(3):416-23.

23. McKinlay A, Cowan S. Student nurses' attitudes towards working with older patients. J Adv Nurs [Internet]. 2003 [Cited 3 Jan 2018]. Available from: https://doi.org/10.1046/j.1365-2648.2003.02713.x

24. Demir E, Saatçioğlu Ö, İmrol F. Uluslararası dergilerde yayımlanan eğitim araştırmalarının normallik varsayımları açısından incelenmesi. Current Research in Education. 2016;2(3):130-48.

25. Öğütoğulları $E$, Kılıç $C$. Türkiye işgücü piyasasında yeni bir problem alanı: 40 yaş ve üstü işsizler. Labor Relationships J. 2016;7(1):85-97.

26. Kaçan H, Dibekli E, Akkan K. The evaluation of ageism attitude levels of individuals in society. Elderly Problems Research Journal [Internet]. 2018 [Cited 15 Dec 2019]. Available from: https://dergipark.org.tr/tr/pub/yasad/issue/41789/ 368469

27. Giardina-Roche C, Black ME. Attitudes of diploma student nurses toward adult clients. J Nurs Educ. 1990;29(5):208-14.

28. Çilingiroglu N, Demirel S. Yaşlılık ve yaşlı ayrımcılığı (Old age and ageism). Turkish J Geriatr. 2004;7(4):225-30.

29. Reuben DB, Fullerton JT, Tschann JM, CroughanMinihane M. Attitudes of beginning medical students 
toward older persons: A five-campus study. Univ Calif Acad Geriatr Soc [Internet]. 1995 [Cited 3 Jan 2018]. Available from: https://doi.org/10.1111/j.15325415.1995.tb06626.x

30. Bulut E, Çilingir D. Yaşlı ayrımcılığı ve hemşirelik bakımına yansımaları. TAF Preventive Medicine Bulletin. 2016;15(5):446-9.

31. Yardımcı Gürel T. Hemşirelik öğrencilerinin yaşlı ayrımcılığına yönelik tutumları ve etkileyen faktörler. Turkey Clinical Journal of Nursing Science. 2019;11(4):381-9.

32. Koç A, Öztaş D, Uysal N, Demircan Z, Erdem Ö, Sarı E. Klinik hemşirelerinin yaşlılara ilişkin düşünce ve tutumları. Ankara Medical Journal. 2018;18(4):500-7.

33. Ogender O, Yapıcı G, Taşdelen B, Akça T. Mersin ilinde bir grup hekimin yaşlı ayrımcılığı hakkında düşünceleri. Turkish J Geriatr. 2012;15(4):409-15.

34. Kissal A, Okan F. Attitudes of health care workers working at family health centers in Tokat towards ageism. Turkey Journal of Family Practice. 2018;22(4):202-12.

35. Naldan M E, Kara D, Soyalp C, Gürol A. Yoğun bakım ünitelerinde çalışan sağlık personelinin yaşlılığa ilişkin ayrımcı tutumlarının değerlendirilmesi. Bakirkoy Medical Journal. 2018;14(1):8-16.

36. Mandıracıoğlu A, Çam MO. Huzurevi çalışanlarının sorunları ve çalışanlar hakkında görüşleri. Turkish J Geriatr. 2004;7:29-32.

37. Rosowsky E. Ageism and professional training in aging: who will be there to help? Generations. 2005;29(3):55-8.

38. Külahçı H. Hemşirelik lisans programı birinci ve dördüncü sınıf öğrencilerinin yaşlılık ve yaşlanmaya ilişkin düşüncelerinin ve görüşlerinin değerlendirilmesi. Dokuz Eylul Univ Sch Nurs Electron J. 2010;3(1):15-21.

39. Kaçan H, Dibekli E, Akkan K. The evaluation of ageism attitude levels of individuals in society. Elderly Problems Research Journal. 2018;11(2):8-15.

40. Okuyan Birimoglu C, Karasu F. Yaşlı bakım personelinin yaşlılara karşı tutumlarının belirlenmesi: bakım sorunları ve müdahale önerileri. Adıyaman University Journal of Health Sciences. 2020;6(1):7783. 